\title{
Editorial
}

\section{Playing the liability game}

Recently, the Big Four Accounting firms sought a cap on liabilities in the UK Companies Bill. This is not altogether dissimilar from the limitation on liability which accountants managed to tack on to the Private Securities Litigation Reform Act 1995 (PSLRA), which requires proof of loss causation for accountant's liability. Among actors in the drama of public companies, accountants are not alone in attempting to shield themselves from liabilities. Directors thus far have been liable only in exceptional cases, but Sarbanes-Oxley has increased awareness of the potential of liability for directors. While the insurance industry has been quick to oblige with such products as portable individual director's insurance, the carve-outs have become increasingly severe and often include such terms as recission restatement. Of course, directors have also sought, and been in a good position to demand, indemnification from public companies in the event the directors' and officers' $(\mathrm{D} \& \mathrm{O})$ liability insurance carrier refuses payment. This second order of defence is generally more generous and subject only to the limitation of an affirmative adjudication of what is tantamount to illegal acts. But then public companies do go bankrupt and, despite the best-laid plans of lawyers, such indemnities may not prove sufficient.

Even in the Sarbanes-Oxley era, directors, like accountants, often fail to put sufficient effort into understanding their affirmative duties. But it is not quite clear that any outside director, in the absence of bad faith or breach of duty of loyalty, has ever been subject to liability under a federal securities law claim. Federal actions against outside directors in Enron and Worldcom have been dismissed for failure to plead scienter with specificity. Similarly, state courts, such as the Delaware Chancery Court, have been wont to find a duty of care, although they have been quite consistent in finding a duty of loyalty (generally an injunction against insider and self-dealing). In fact, after a case found several prominent directors liable, Delaware enacted Stat. 102(b)(7) which allows corporations to amend their charter to shield directors from monetary damages for breach of fiduciary subject to several exceptions including (1) breach of duty of loyalty, (2) intentional misconduct, and (3) bad faith. But in 1996, the Chancery Court in In re Caremark International Inc. Derivative Litigation stated that a director's duty of care includes a duty to attempt to ensure that a corporate information and reporting system exists and that failure to do so, at least in theory, renders a director liable for losses caused by non-compliance with applicable legal standards. In certain cases since the enactment of Sarbanes-Oxley, the Delaware Chancery Court has indicated that other circumstances, such as complete failure to review Michael Ovitz's compensation package in In re Disney Litigation, might give rise to a duty of care.

In Lernout and Hauspie, the court has gone as far as to determine that audit committee members may be controlling persons under section 20(a) of the 1934 Act. The district court held that such members had 'possession, direct or indirect of the power to direct or cause the direction of management and the policies of a person'. The court also stated: 'An outside director and audit commitee member who is in a position to approve a corporation's financial statements can be presumed to have "the power to 
direct or cause the direction of the management and policies of" the corporation, at least insofar as the "management and policies" referred to relate to ensuring the accuracy in the content of company reports and SEC [Securities and Exchange Commission] registrations they actually sign' (286 B.R. 332002 citing In re Livent Inc. Noteholders Sec. Litig. 151 F. Supp. 2d 371, 437 S.D.N.Y 2001). This case did not even rely on SarbanesOxley, but the enhanced power of the audit committee under section 301 makes directors more likely to be considered to have the power to direct corporate management.

This Massachusetts case is hardly the rule of law beyond this part of the first circuit, however, so no one should get carried away about directors' liability. Derivative litigation in Delaware raises the bar at least as high as the PSLRA, and class action lawyers have been largely unsuccessful in getting pieces of directors' hides. The average director has about as much chance of being held liable as the average high school dropout has of becoming a director of a Standard \& Poor's (S\&P) 500 company. The chance that a director will have to shell out of his or her own pocket is so infinitesimal that it need hardly be considered (in one instance a venture capital firm to which a director belonged did go out of pocket). Being a director involves general rather than professional liability. The circumstances in which directors might eventually face liability will involve complicated fact patterns in which directors are shown to be aware that financial statements do not accurately reflect the financial condition of the company, whether under the negligence standards of state law or the recklessness standard of the PSLRA. In other words, a pittance of knowledge would suffice for such a director to realise that he or she is open to liability. Thus, unlike management which faces serious questions in the event of a restatement, has certified financial statements and internal controls, and in the first instance faces severe criminal penalties in the event of a false certification, directors in general need not play the liability game.

In the current season of high earnings growth, the question of directors' liabilities may have been placed on the back burner. But the shape of things to come indicates that directors are likely to be placed in the hot seat. Initially, several academic perspectives such as the team theory of production and other entity theories of the corporation had suggested that directors are best placed to mediate the interests of the stakeholder, especially shareholders and officers. Section 301 of Sarbanes-Oxley, by placing the audit committee both in the position of hiring auditors and at the top of the pyramid in instances of whistleblowing, will inevitably cause members of the audit committee, and the full board in the event such matters are reported to it, to be exposed to greater liability. Directors, even financial experts on audit committees, may find that they are woefully unprepared to meet these responsibilities. Over the long term, directors' compensation will follow the same upward trajectory as D\&O insurance premiums. In the meantime, despite increased compensation, many directors are unaware of the responsibilities they have assumed. While the Higgs Report and NYSE rules mandate directors' training, one can only hope that directors take this as more than a pro forma requirement and that they receive adequate instruction.

How then will the federalising of corporate law alter the corporate governance dynamic, if not by holding directors liable? Nowadays, corporate governance is becoming an ingredient in market value, and S\&P has a new corporate governance rating system. What it puts in the mix, one can only suppose, since Nationally Recognized Statistical Rating Organizations (NRSROs) are not subject to Regulation Fair Disclosure (FD). But the focus on directors, while it might not immediately solve the age-old agency problem, will certainly change norms. 
Directors are working longer hours, perhaps needlessly concerned by the liability stick, but also aware of new-found prestige and responsibility. Compensation for directors, particularly audit committee members, is up substantially, although it still does not begin to compensate for really meaningful responsibilities.

But directors have reputational capital that requires a good faith effort to perform reasonably. Only two years ago William Webster, who had been a director of a public company that went belly up under mysterious circumstances, came close to being named the first chairman of the Public Company Accounting Oversight Board (PCAOB). By placing directors in the forefront of corporate financial reporting, the Sarbanes-Oxley section 301 requirement that the Audit Committee appoint the auditor and meet with the auditor outside the presence of management is bound to change the dynamic by which corporations are governed.

Reputational capital is a far more serious concern for directors who realistically appraise the risks they face, including the nuisance of being a named party in litigation rather than legal liability itself. In this respect, the events at Hollinger International which have tainted Henry Kissinger, the former governor of Illinois, and Richard Perle will go further than decisions of the Chancery Court to encourage directors to accept the extent of their legal responsibilities (Richard Perle, having reputedly had knowledge of illegal acts, might, even under Delaware's restrictive statute, face liability for failing to disclose what Lord Black had told him).

The most specific instance in which directors may improve their performance concerns financial reporting and the hiring of auditors. In this regard, directors, particularly audit committee members, should be aware of just what services the auditors are performing and which services are handled by internal auditors and other consultants. While the audit committee must specifically approve all consulting services, the committee should become aware of what ingredients and processes are involved in the preparation of 10-Ks and Qs, with particular reference to section 404 internal controls.

Audit commitee members should know the roles played by the internal auditor(s), the external auditor and the designer of internal controls and how these responsibilities are best delineated in light of the SEC regulations concerning the separation of audit and consulting services: how information flows in a system with checks and balances. While no such speciic duties can be inferred under Sarbanes-Oxley, this level of understanding is essential in terms of 'best practice'; and while no one can prognosticate how judicial doctrines regarding directors' duties will evolve, the direction, if not the pace of change, which laws relating to directors' duties will take is abundantly clear. Those companies which adopt forward-looking governance structures will find themselves at an advantage in the new regulatory environment.

Mr John Friedland Editor 